人腹水腫湯細胞の組織培盖に上る形態学的研究

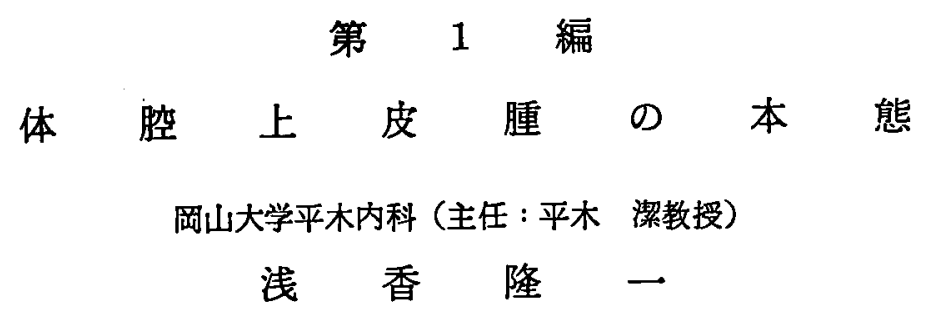

〔昭和 34 年 6 月 6 日受稿〕

第 1 章 緒言

第 2 章 研究材料及已゙研究方法

第3 章 研究成績

1) 讼抹固定架色

2）組織培養

3) 生体染色

\section{第1章 楮言}

体腔上皮腫の本的に関しては，古今を通じで多く の学者達が色々と説をたてているが，未だ単格な意 味でその本热を結論するに至つていない現状である。 元来悪性属湯の診断に当つて, 我々は好んでその母 組織模做性を拠り所にするか，現今の知識では腫場 の母組織を適確に決定する事は容易な業ではない。 幸いに母組織を決定し得たとしてあ，腫瘍芽の時期 を見たのでない限り，てれが正常の局所細胞から発 生したものか, 或いは胎生期の迷芽または組織畸形 部から発生したかを訩断する事は更に困難である.

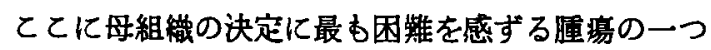
に，所謂内皮腫と呼ばれるすのがある．との場合血 管及びリンパ管の内皮腄は除外して，顔面，頸部䑏 器更に胸・ 心重・腹膜加発生する内皮腫加問題之 なる. Wagner(1870) が肋膜に原発した腫演を内皮 癌として始めて記载し，Benda2)(1897) は肋膜の原発 腫場を報告して，実質細胞は䈋膜細胞か腫場性増殖 を起したものであると結諭した。そこの後 Nappd1) (1906)，Götting 17) (1909)，Krumbein 39) (1924) 等 多数の賛成者を見たか，Hamdi20)（1929）か胸・心 哓・腹膜に原発するこの腫察を綕称して Coelothelioma なる名际を提昌してドイッ病理学者の注目を ひいた，本邦ではての堙晹は従来内皮腫，或いは内 皮細胞扂などと呼ばれているが，その組織発生学に
次

4）琶粒領喰

5）王挫による位相差顕微鏡䔘察

6） T.P.T. 反応

7）細胞浮游液培養による位相差顕微鏡観祭 第 4 章 総括並びに考按 第 5 章 結 語

関しては特別な注意が払われていなかつた：浜崎18) 教授は多年腹膜の研究を続けた結果, この腫場の組 織発生に関して漿膜細胞説を信じ Hamdi20) の提唱 した Coelotheliomaに賛し，てれに体整上皮腫なる 邦訳を与え，爾来この名称が国内に通用している. 元来本唓場の名称としては, 胎生学的に上皮・内皮 に対する定義に基く His 24 (1927) の䈋膜内皮腫な る古典的名称が生れたのであるが,垷在はHertwig23) (1915)の Coelomtheorie (体轰説) が一般に認め られたために本腫㷧を内皮腫上呼ぶのは不合理であ るとされ，体䶼上皮腫 (Coelothelioma) と中肧葉 上皮腫 (Mesothelioma)なる名称が是認されてい

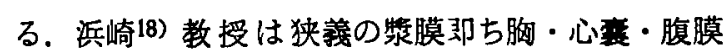
を総称して Coelothel と呼ばれる所から前者即ち Hamdi20)の提唱した Coelothelioma なる名前が最 あ適当であると云い, 後者はアメリカで好んで用い られているが Mesothel とは狭義の整膜ばかりでな く広く尿生殖器更に関節腔・脳膜上皮をも意味する 加ら好ましくないと述へている.

然るに Fischer-Wasel812)(1932) は以上の所説 はいずれるこの腫場が漿膜細胞から発生した確寒な 証趣を握つていない事を強調して反論した. 最近 Campbel13)(1950) は自家経駼つ 4 例を中心として ての腫場の特改及び監別晾断を列挙しているが，理 論的には Fischer-Wasels の及坟を覆えすに足る論 拠をあげていない，一方浜崎 ${ }^{19)}$ 教摱等は最近 4 例 
の人体組織所見之白䎼の体腔上皮腫について腫煌学 的に再検討を試み，殊に白国においては体腔上皮䭪 の腫韵芽を実験的に形成せしめる事に成功し，厳格 な意味で体腔上皮腫が漿膜細胞からの原発性腫場な る事を結論している.

以上体驾上皮腫が洯膜に原発する特貲なる腫煌で あるという事は, 一部の学者を除いて臨床, 病理, 胎生, 生物学などあらゆる部門の研究により現今概 ね是認せられてはいるが，総て従来の本腫湯細胞に 対する細胞学的検索は, 単に死後固定染色により行 われているものであつて，生態観察を主体としたそ の詳細なる形態学的吟味乃至は整膜細胞之の対比検 討は全く試みられていない，私は最近教室に於いて， 臨床的にあらゆる検索にあ拘らずその原発病巣を確 認出来なかつた， 3 例の腹水腫場細胞を有する患者 に遭遇し，腹水細胞の塑抹固定染色により明らかに 䈋膜細胞との移行像を示す体腔上皮腫細胞を認めた。 そこで私は本腫湯細胞に対して, 教室考案の組織培 美を中心とした多くの生態観察（動態観察, 位差顕 微鏡稓察，生体染色，墨粒会喰等）を集中してその 細胞形態学的解明を試み，一方正常腹水の漿膜細胞 に対しても同様の生態観察を試み，乙れと対比検討 した結果，固定染色摽本以上に本腫㗟細胞之漿膜細 胞との明確なる移行を把握し得たと共に，本腫湯細 胞の形態学的特徽を卯加開明する事が出来たのでて とに埌告する。

\section{第2 章 研究材料及び研究方法}

1. 研究材料

1）人正常（非病的）䧗水採取 . 外科にて開腹 した患者の中，直接腹水に影響のない胃溃掦（非穿 孔）を選ざ手術時毛細管で採取した，正常腹水は極 く少哩より $1.0 \mathrm{cc}$ 程度採取に成功し，乙の中全く 赤血球を含ま如例を锤察に供した。

2）患者腹水採取：体腔上皮腫患者 3 例の腹水 穿刺液を検索した。

\section{2. 研究方法}

1）染抹固定染色 . 腹水沈渣を叙抹固定し, May Giemsa 染色, Giemsa 染色に上つた。

2）組織培羡：海野氏打抜硝子による被覆培港

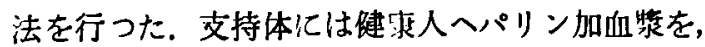

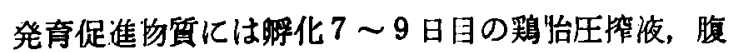
水上清を使用した，即ち穴の片面を覆える被復硝子

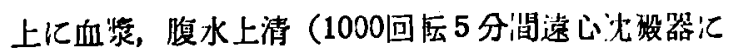

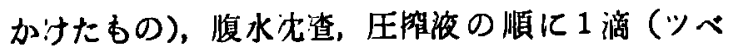

ルクリン針 1 滴）づつ滴下し，片面を更に被覆硝子 で覆い，周囲をパラフィンで封入し， $37^{\circ} \mathrm{C}$ 捊卵器 に入れる，観察は同温の保温箱で行つた。

3）生体染色上記組織培養汇培地濃度 $0.01 \%$ の中性紅，0.001\%のヤーヌス緑を添加した。

4）墨粒頜喰： 同組織培夏に紅花黒をリンゲル 氏液で一定濃度に磨つたものを 1 滴添加した。

5) 压挫に上る位相差顕微鏡観察：0.9 1.0mm 溥さの良質の載物硝子に腹水沈渣を 1 滴載せ, 被稪 硝子で覆い，周囲をパラフィンで封入した．レンズ は DM，BM，DLL を用い，1000×で観察した。

6） T.P. T. 反応：腹水沈渣 1 滴を載物硝子に 載せ, 之に $1 \%$ T. P. T. 生理的食塩水を 1 滴添

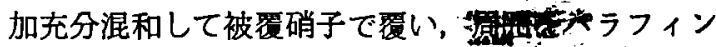
で封入し， $37^{\circ} \mathrm{C}$ 睬卵器に入れる。: 1 時間後より観 察を開始した。

7）細胞浮游液培羡による位相差顕微鏡観察・ 第 2 編にて述へる培養法で培養した腫湯細胞を，各 時期に適当に取出し前記圧挫法で処理して観察した。

\section{第3章 研究成 綪}

1）噇抹固定染色

（i）人正常漿膜細胞 :

一般腫場細胞之略々同大の大型細胞で，核は普通 1 個，稀に 2 個の時あり，核形は類円形が压倒的に 多く，核境界は明瞭円骨で，核膜厚く，核陥凹や， 核截痕を見ない，核網は緻密で規則正しい網眼を形 成し，核色質は微細で顆柆状に現われ，核表面に分 葉㑯向全くなく平滑であるため恰もンーセージの断 面を思わしめる，核は一般腫增細胞之比校して谈架 し，炏凊色に染まる 1 万至 2 個の核小体をみる事あ り，一部には核色質集合部す存在するがその境界は 不明瞪である。胞体縁は凹凸にそしく至極不鮮明，

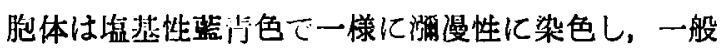
腫场細胞の原北澌と比恔して清朋で塭基度強く，顆 粒状乃至雲絮状の構造は認められず，空胞出現は殆 んどなく，又如何なる顆柆も染まらない，単離状の 事ああるが $2 \sim 3$ 個連結している事ああり；その時 は胞体は不定形を呈する。

(ii) 体䐑.上皮喠緗胞

一般腫寄細胞と比悛して小型細胞が少なく，大型 細泡が多い，核は普通 1 㤥であるが，桸伅多恔性を 有する事がある．核形は類问形を呈する事が多いが， 核境界は不規則，不明煌刀場合が多く，核截作，核 陥凹を見ない，核網は不整で，核内に異常透亮部が 
あり，荟淡著明で均一ならず，核内には大型の核小 体及び大小不同の多数の核小体を有する事が多い. 胞体は狺淡入り乱れて極めて不整で，中には核周の 一部或いは全周任亘つて不定型の核周異常焱染部が あり，又胞体縁に近つくにつれて胞体肥厚感が伴な い，乙の部は核周辺部に比へて強く濃染する傾向が 認められる. 又胞体には核同様に不定形異常透亮部 が明瞭に存在する事が多い，胞体縁は極めて不分明 且不整であつて凹凸を形成し，胞体の一部或いは全 周より㣪状乃至鞭毛状の細突出物が多数見られる。 尚この細突出物は一般腫痬細胞と比較して本細胞の 特徽的所見之云い得る。

以上体脖上皮腫細胞の塗抹固定染色では，核小体 の異常, 細胞内随所の不定形異常透亮部, 核縁肥厚, 細乫出物等が特異的で, 明かに一般腫湯細胞之同様 悪質性を疑うに足る充分な所見がみられるが，一方 円形で均質に谈染した核を有し漿膜細胞を思わせる が，核小体に大小不同あり胞体の濃染した細胞があ り，明ら汃両細胞の移行像の存在する事加認めら れる.

2) 組織培盖 (被覆培養)

(i) 人正常漿膜細胞 (写真 1 ):

本細胞の大きさは，塗抹染色で述へた如くであり 形は略々円形である。核は胞体の中心にあるか又は 偏在し，核内は無構造て同大円形の明暸な核小体が $1 \sim 2$ 個認められる事が特異な点である. 胞体縁は 明確で鹤足突起なく，胞体内には極く微細な顆粒が 同心円状に規則正しく配列し，核周にはやや大なる 顆柆がやはり同心円状に散在している事む特異であ る. 又本細胞は病的腹水のそれ比し老化せるむの が多く，変性顆粒も早く現われ，核周より生じてく る.

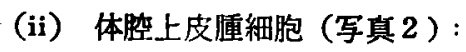

本細胞の大きさは大小不同種々あり，小なるもの は漿膜細胞大より，大なるものはその 2 倍大迄ある。 核は偏在し2個以上の事も稀でなく，核膜は一般腫激 緗胞程厚くない，核内は無秿造なるも大小不同の核 小体を認め，紫膜細胞に比し異常で明らかに腯湯性 格を示している. 胞体縁は明嘹で, 細胞企体として 一般腫煬細胞より稍ふ房平な感じがあるが，敬膜細 胞に比すると明らかに重厚である. 又脆体内には極 く微紐な顆粘が多く存在するが，その分倠は不损則 で，紫膜緗胞の如き徥則正しい同心户状配列付示さ ない．然し個々の顆粒は一般腫㻛細咆に比し微紐て， 紫膜細胞の顆粒と類似している. 更に本紐胞の特哄
性と思われるものの一つとしてその僁足がある．即 与培荃後 2 時間们於いて，早くあ胞体の一部が丘状 に盛り上り，その部より赖状の突起が密生している のがみられる. 少し変性したあのは, クラッカー状 或いは花弁状の偽足を胞体の所々より出沒させる. 又或るむのでは，胞体之同大の舌状偽足を出沒させ るむのむある. 更に本細胞に特有な事は大空胞を生 じ易い事で，展々それ等が折り重なつて認められ， 一つの細胞に $3 \sim 4$ 個の大空胞を認める事がある.

以上本細胞の組織培羡（被覆培養）では，核小体 の大小不同, 多種多様な偽足, 大空胞形成等明らか に腫韵性格を認めるが，核膜，胞体内顆粒について はその質, 量的関係より漿膜細胞之の移行像が認め られる。

3）生体染色

(i) 人正常漿膜細胞 (写真 3 ):

中性紅顆粓は認められない.

ヤーヌス緑顆粒は短桿状或いは点状で，培養直後 より核周に同心円状浔められるが，その分布密度 は核の周辺帯に密で, 胞体縁部に近つくに従つて疎 となり，てれは本細胞に極めて特異な所見である。 又核偏在性のものでは原形質の広い側の核辺に集簇 性に存在する. $2 \sim 3$ 時間で染色率, 染色度共偮 高となり，4〜5時間後より泍次腿色を始め $7 \sim 8$ 時間で脱色する。

（ii）体胫上皮腫細胞（写真 4)

中性紅顂粒、は，小顆煜より大空胞に至るまで種々 の大きさのあのを混在するもの, 略々同大の中性紅 顆粒で充満するもの等細胞により極めて多彩で，そ の分布状態む主として原形質の広い部の核凹部に集 箔性にあるもの，胞体内に不規則に散在するもの， 更に胞体内を箱漫性に染めるもの等多様であるが, 細胞の変性度の少ないものでは概して核凹部又は核 周に集簇し, 個々の中性紅顆粒も鮮明て独立性を保 つている.

染色は30分後より鮮明な色調を呈するが，染色率， 染色度は $3 \sim 4$ 時間後に最高となり，5〜6時間後 より褪色を始め変性の少ないあのでは12～15時間に 及ぶ. 次に印環細胞の多数出現する事は本腫瘍の特 徽であるか，又生体染色に於いては中性紅に一椂に 热色された大空胞を有する細胞即ち空胞染色性印環 細胞の出現率高き事が特異である.

ヤーヌス緑顆粒は粒状乃至点状, 短系状て繁膜細 胞のむのK比し稍々大小あり，その配列は古有顆粒

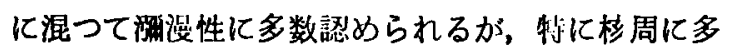


く，多核性のものては核凹部任集簿性があり，又中 性紅空胞の周りにも多い，然し前記残膜細胞の如き 規則的な分布は見られない，一方極く一部に，榜周 に同心円状の配列倒向を止めているものがあり，こ れは本細胞之漿膜細胞の移行型之考えられるるので ある. この顆粒は生染直後より認め， $2 \sim 3$ 時間後 亿染色率，染色度共に最高となり，4 時間後より褪 色するが消色は 7〜10時間後である.

以上体佶上皮腫細胞では，生体染色度が一般腄晼 細胞より強く，食細胞に匹敵する程であるのは特徵 的である．一面ヤーヌス緑顆粒の配列が同心円状之 なり繁膜細胞之の移行像を思わせるむのがあるのむ 特異所見である。

\section{4）舅粒頜喰}

（i）人正常漿膜細胞

一般に陰性であるが，稀に 1〜2 個の黑粒を原形 筫に孤立性に認めることがある。

(ii) 体腔上皮腫細胞:

本細胞でも陰性であるが，知㖘り稀倍盖 $5 \sim 6$ 時間後に孤立性に 1 ～2 個の墨粒を認める事がある.

5）厈挫による位相差湿微鏡観察

（i）人正常漿膜細胞 (写真 5 ).

一般腫汮細胞之略々局大の円形の細胞で，核は円 形で略々胞体の中央にあり，核，核膜共に屁光性は 中等度である，核小体は屈光性强度にて，円形同大 のむのが 2 数個認められる. 胞体縁は明瞭にして, 偽足突起なく胞体・核比は胞体がかなり優勢である. 胞体は清明で，胞体内には糸粒体以外には顆粒とし て認められるあのは殆んどない. DLLにて鈍黒の 糸状の系粒体が核を中心として同心円状に配列され ている事は，本細胞の特異的な所見である。

(ii) 体腔上皮腫細胞 (写真 6 ).

細胞の大小不同が極めて甚だしく，且つ多種多粎 な形をとつている．即与多核性，対細胞，大空胞性 等がみられ，更には多数の細胞がシートを作り連り

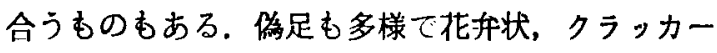
状，紫状，刷毛状などがある．然し一般腫晹細胞に 比し細胞全体として扁平な感じがある，核は類円形 で核質に富み婮光性强く，核小体は大小不同，不整 であり，乙の点漿膜細胞と異なり腫捼性格を現わし ている. 胞体縁は明膫て，上記の多彩な伪足との移 行は判然としている．偽足の出入はクラッカー状の ものではかなり活泳に見られる。然し細胞企体とし ての位置移動は通常の钼察下では見ら机ない，胞体 内には，核を中心に同心円状に DLLにて鹳組鈍黒

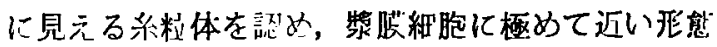

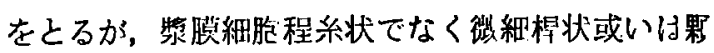
粒状のものが多く，且つ数も多い，更に本細胞に特 買な点として，脆体内に大小不同の空胞が見られ， 更に又杉を一方に圧排した大空胞を有するものもみ られ，悲者から採取した直後の䧗水では，むしろか かる空胞を有する細胞の方が多い.

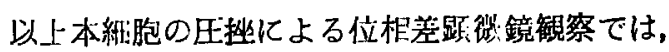
多皤多様な細胞形, 核小体の大小不同, 大空胞形成等 明らかに腫瘍性格を認めるが，一面系粒体の形態に 於いては漿膜細胞に颣似した性格を哯う事が出来る。

6) T.P. T. 反応 (Triphenyl Tetrazolium Chloride 反応)

(i) 人正常敃膜細胞 :

全く陰性である.

(ii) 体腔上皮細胞 (写真 7):

30分後より赤橙色乃至真紅色に染つた略々同大の T.P. T. 顆粒を認め，その数は $1 \sim 2$ 個の少数から, 脆体内に克満性に多数存在するあのまで多種多様で あるが，その染色率，平均染色度は共に他の睡埸細 胞に比して低い。

以上本細胞ては T.P.T. 反応陽性度が低く，從つ て腫㿋性格力、低い事がうかがわれる。

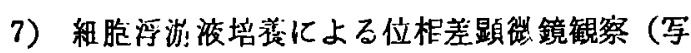
真 8,9 )

訝細については第 2 編にて述へる予定であるが， 体燃上皮腫細胞の培養を開始すると，既に稍《変 性を開始していた細胞け次第に変性脉壊に陥り，一 方 3 日目頃から核分裂が起り新生細胞が出現してく る. 即ち 5 日目の新生科胞を見ると一般腄瘍細胞に 此し大型細胞が多く，且つ扁平な感じである，核は 略々中央にあり，円形で核優勢は軽度，核膜は压挫 の時と同じく一般腫激細胞に比へると厚くない，核 小体は 2 個が多く，時に 3 個あり余り大型でなく， 又大小不同む著しくなく腫湯性格が低い，胞体は压 挫の時に比し非常に清明で空胞は全然無く，辺縁の 偽足形成も殆んど盡い，只細胞の紹合部の跡に特有 の一束の針状突起が見られ，恐らく細胞間の結合糸 と考えられる. DLL にて鈍黒の糸粒体が，核の周 囲から胞体全体にわたり同心円状に配列され，極め て細小紎である，一見整膜細胞の系粒体之極めて 類似しているが，悩を蜼れるにつれ必らずしむ同心 订状にならず，微練な網状を形成する事及び遙かに 数の多い事が漿膜細胞とは異つている.

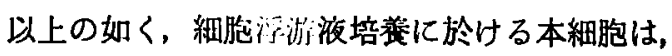


形態学上の腫煌性格が低い事が特色であり，又一面

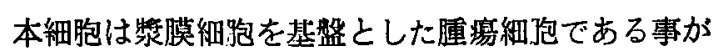
明らかで，王挫の時以上に漿膜細胞との移行型が数 多く見られる。

\section{第4章 棇括並びに考按}

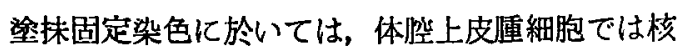
小体の異常, 特にその大小不同を認め, 又細胞内随 所の不定形異常透亮部，核緑肥厚，胞体縁全周或い は一部よりの細突出物を有する事等は特異的で一般 腫場細胞之同様に恶質性を疑うに足る充分な所見で ある. 一方核は怔膜細胞に類似しているが, 核小体, 胞体には体㚙上皮腫細胞の修態を示し，明らかに而

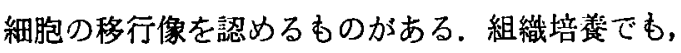
体腹上皮腫細狍は大小不同の㤥小体，多種多椂つ伪 足及びその運動, 複雗怪奇な大空胞形成を認める事

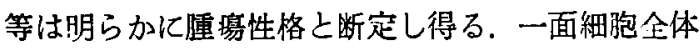
としての扁平な感し，核膜つ薄い事，胞体内個々の 顆泣の钽細な事等は腫湟性格の低い事を示し，又同 時に漿膜細胞之の移行を思わせるに足るすのである。 生体染色仿於いては，体腔上皮腫細咆は一般腫瘍細 胞に比し染色度加強い，一方本細胞では，その一部 ではあるが，ャーヌス緑顆粒が㤥周に同心円状配列 傾向を示し，湬膜細胞との移行を示している．䍐煜

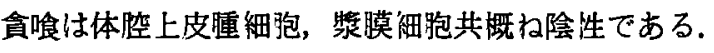

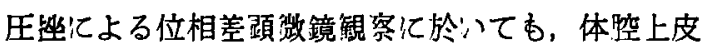
腫細胞は多種多様な形態を呈し，又多移な偽足及び その運動，大小不同及び不整つ核小体，大空狍形成 等が認められる事は明らか汇悪質性を示している。 然し乍ら細畇全体としての扁平感, 核膜つ薄い事,

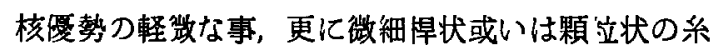
粓体が胞体内に核周より同心円状に配列されている 事等は漿膜細胞に極めて近い形態を提示するすので ある. T.P.T. 反応でも，体腔上皮腫細胞は一般腫

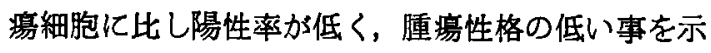
している，尚䈋膜袖胞は T.P.T. 反応陰性である。

細胞浮游液培養による位相差頙微鏡観察では，圧 挫の時に比し更に漿膜細胞之類似した形態を示す. 即5 5 日目の体腔上皮腫細胞は非常に清明であり。 核膜は明膫で厚くなく，核優勢も㹩度である，又核 小体は余り大型でなく，大小不同む著しくなく，空 胞, 偽足屯認めない，更他胞本内に細小系状の系柆 体が核を中心に同心円状に配列されている状態は恰

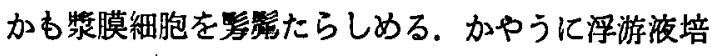

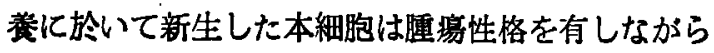

む，正挫の時に比し更に悪質性が少く，一方嶈膜細 胞に極めて類似した形態を呈している.

脽膜から一種特異な隀痬が発生する事即与体腔上 皮腫なる埋湟が存在する事，及びそ机が獎膜細胞に 由来するあのであるという説は現今一部の学者をの ぞいて多数の学者但よつて支持されるに至つている. 上村，武田51）は死後腹腔漿膜面組織のへマトキシ リン・エオジン染色により，紀錘形の実質細胞を認 ๖，夫は新しい結節部では直接腹腔に露出しており， 又その㤥は類円形で核膜には凹凸がかなり目立ち， 核仁は明瞭住認められ，朋らかに整膜細胞を基盤と する細胞であると述へている，又浜㥓19）教授等は

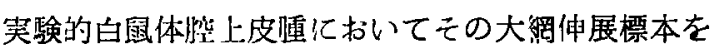
榆镜し，網菜の漿膜細胞は旺んに肥大增殖して木瘤 状の結筇を作り，尖つ深尿の細胞はやや扁平な形を なして重つているか，士層に進む程円形に肥大し核 あ大きく核仁及び掏色素立が相大となり，更に結節 か渐㭙大きくなると表層つ細胞法退北或が強く，乙 れが腹㒄へ游離すると述へており（尚同教授は本細 胞は吉田肉腫細胞之区別がつかないと云う), 漿膜 細泡から腫瑒細泡への移行を病里組織学的に確認し ている. かやうに従来の本腫場細狍に対する細狍学 的検索は, 単に死浽腫痬組織つ固定染色に上り, 病 理組織学的に漿膜細狍よりの移行を確涊しているに 過ぎず，その単猚細胞の詳細なる形態学的吟味乃至 は単蜼細包としての整膜細狍との対比検討は, 全く 顧みられていない，私は以上の如く本唓湯細胞に対 して，教室考案つ組織培養を中心とした多くの生態 観察を集中して検索した所, 何れの㭘索法汇於いて

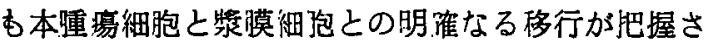
れたが，特に私の新しく考案した Roller-tube に よる細跑浮游液培羕法汇上り新生した本細胞に於い ては整膜細胞との移行像か極力て歴然上現われ，そ てには何等疑う余地が残されなかつた。

即与組織培養に基く生態観察汇より，体腥上皮腫 細胞は漿膜細胞を基盤とする腫湯細胞ごある事が, 新たに確証せられたよ云つてよいであろう。

次に同様の観察所見からみると，本腫啺細胞には， 他の董㩐細胞にはみられざる種々の将異なる多くの 特徽が見出されたが，こ机を要約すると次の三大特 色之云い得る. 即ち先ず本細胞は一般住扁平な感じ

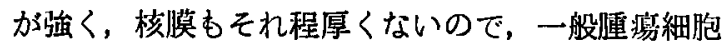
に比して形態学上の腫漡性佫が明らかに低い，次に 本細胞は多種多様な偏足を有し, 然もそれを活泳に 運動せしめる. 次に本細胞は他にみられざる複奞怪 
奇な大空胞を形成する．乙れらの所見も従来全然知 られていない所であつたが，私の生態観察に於いて は一見して極めて明確であるので，今後細胞晾断上 重視すバきである.

\section{第 5 章 結 語}

人正常（非病的）腹水中の繁哭細胞之 3 例の体陪 上皮腫患者腹水中の腫㻛細胞につき，教室芳案の組 織培恙を中心とした多くの生態篗察を行い，両納胞 を比較検討した。

1）塾抹固定染色では，体沿上皮尰細胞は明らか に悪咓性なるも，種々の質的関係より漿脱細胞との 移行のある事を認めた。

2）組織培琹では，核膜，胞体内顆柆等について 両細胞間の移行を認めた。

3）生体染色では，胞体内ヤーヌス緑顆柆の分布 状態により移行を認めた。

4）墨柆貪嗅は両細胞共陰性であつた.

5）王挫に上る位相差預微鏡㷷察では，核膜，核 俊勢度，系粒体の配列状態等に於いて軕細胞の移行

\section{像を認めた。}

6） T. P. T. 反応では，体腔上皮腫細胞の腫晹性 格の低い事を認めた。

7）練胞浮游液培美による位相差颛微鏡観察では, 圧挫の時以上に両袖胞の移行型を認めた。

以上により，体腔上皮腫細胞が漿膜細胞を基盤と する細胞である事が確認されたが，更に本腫晹細胞 は一般に扁平な感じが強く，多種多様な偽足形成及 びその活発な運動を有し，複稚怪奇な大空胞形成を 認め，乙れらは本腫浧細胞の 3 大特色と云い得る事 が明確に認められた。

稿を終るに臨み終始御怒切なる御指導と御校閲を 賜わりたる恩師平木泚教授业びそ大藤真助教授飞深 潡の意を捧ける。

本論文の要旨は第19回日本血液学会総会业び飞第 49回日本消化機病学会飞於いて発表した.

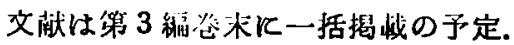

\title{
Morphological Studies on Human Ascites Tumor Cells by Tissue culture
}

\section{Part 1. The essential traits of coelothelioma}

\author{
By \\ Takakazu Asaka \\ Department of Internal Medicine Okayama University Medical School \\ (Director : Prof. Kiyoshi Hiraki)
}

By carrying out vital observations on serous cells of ascitss in normal persons (nonpathologic) and on tumor cells in the ascites of t'aree patients with coelothelioma mainly by means of the simple culture method devised in our department, the author compared the results of the two observations, and obtainet th 3 following results.

1. In the smeared and fixed specimens coelothelioma cells show clearly malignant traits, but on examining them more scrutinously the transition from serous cells can be recognized.

2. In the tissue culture the nuclear membrane and cytoplasmic granules all indicate that serous cells are being transformed into coelothelioma rells.

3. In the vital staining the manner of distribution of cytoplasmic granules stained with Janus green also indicates the transformation of both cells.

4. The carbon-particle phagocytosis in both cells prove to be negatice.

5. When these cells are prepared by compression metiod and o'sserved under a phase- 
contrast microscope, from their nuclear membrane, increased nucleo-cytoplasmic ratio, and mitochondria distribution it can be understood that there exists a trasitional type of cells between both cells.

6. In T. P. T. reaction, the tumor characteristic of coelothelioma cells is found to be weak.

7. In the phase-contrast microscopic observation conducted on the tissue culture of both cells in suspension, more transitional type of both cells can be recognized than in the case of compression method.

From these observations it has been confirmed that coelothelioma cells are fundamentally derived from serous cells, and that these tumor cells are generally flat, possessing various pseudopodia which can move actively and they have complicated pecuiiar large vacuoles, and that these can be construed as three great charateristic traits of these tumor cells. 


\section{浅香 論 文 附 図}

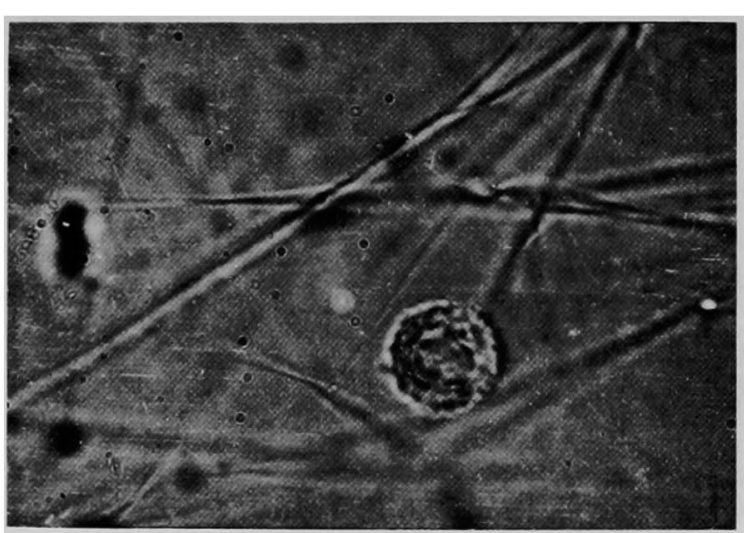

写真 1 人正常洯膜細胞（組織培養）

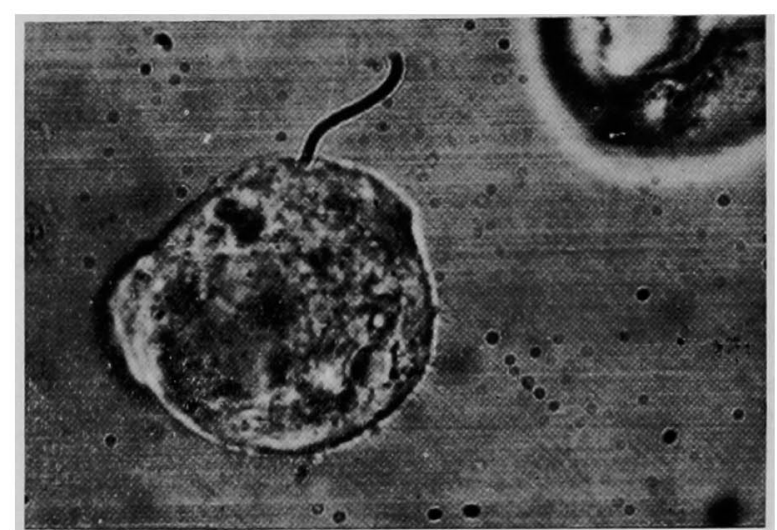

写真 2 体腔上皮腫細胞（組織培養）

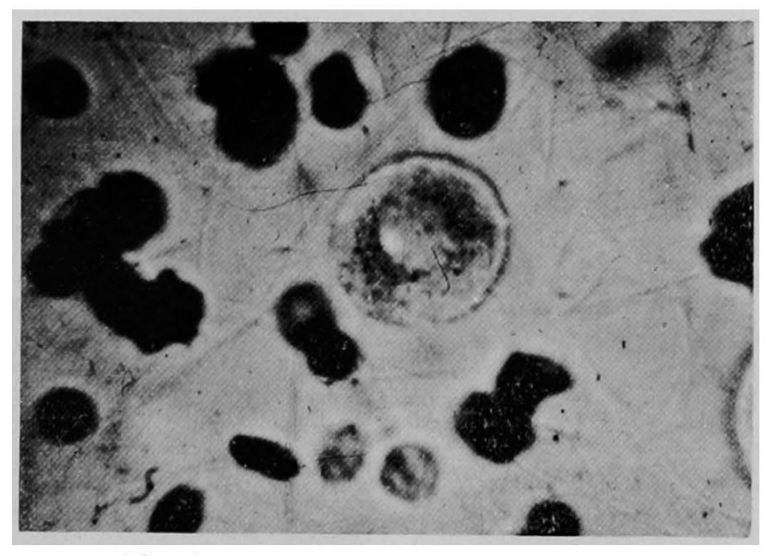

写真 3 人正常䈋膜临胞（生体染色）

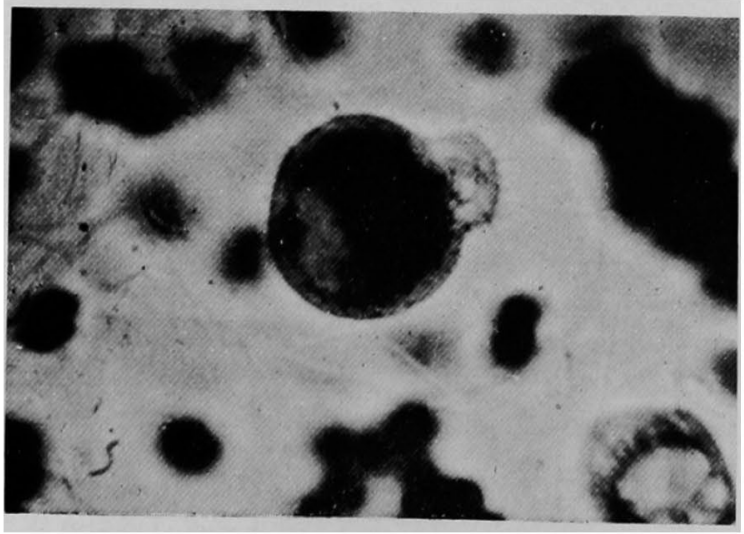

写真 4 体㓐上皮腫細胞（生体染色）

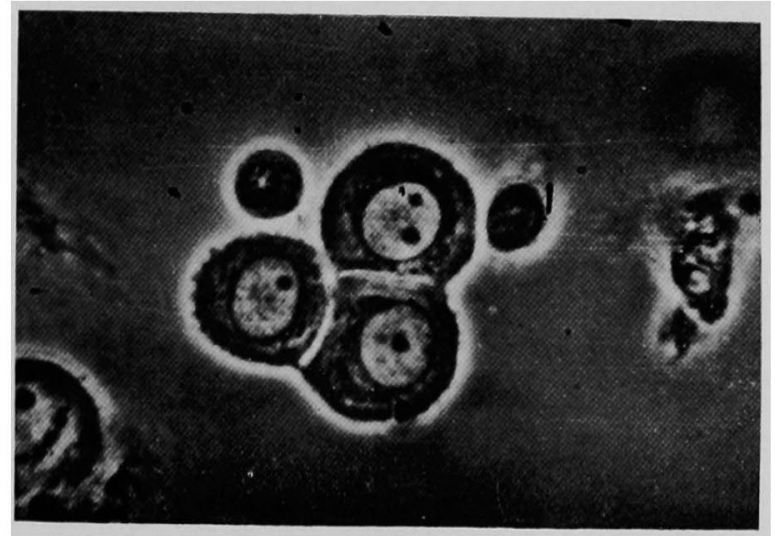

军真 5 人正常蟼膜細胞 (PCM-DLL) 


\section{浅香 論 文 附 図}

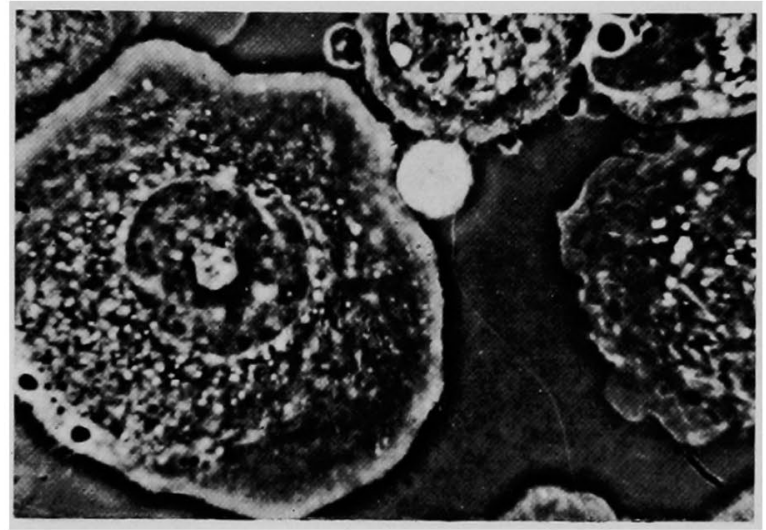

写真 6 体腔上皮腫細胞 (PCM-BII)

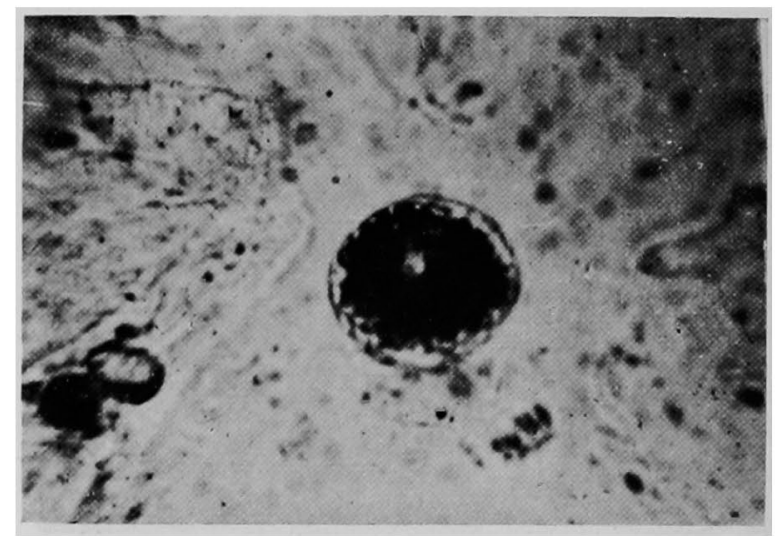

写真 7 体医上皮腫細胞（T. P. T. 反忍）

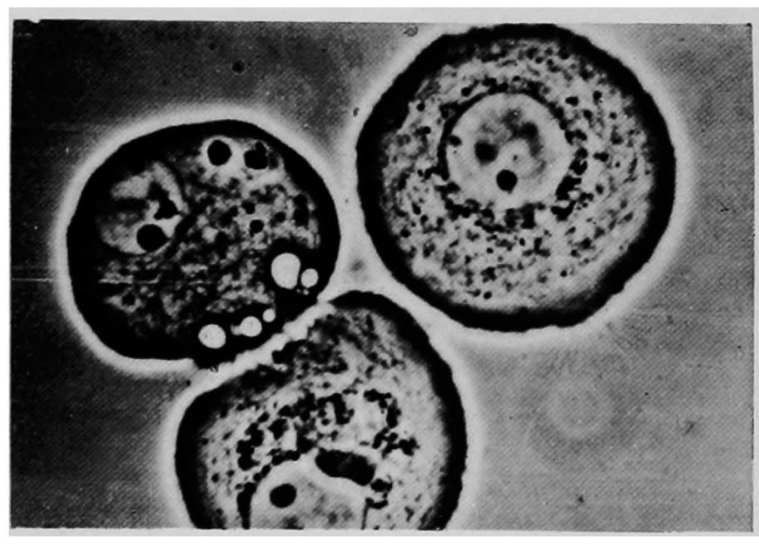

写真 8 体腔上皮腫細肥 (细胞浮遊液培 PCM- DLL)

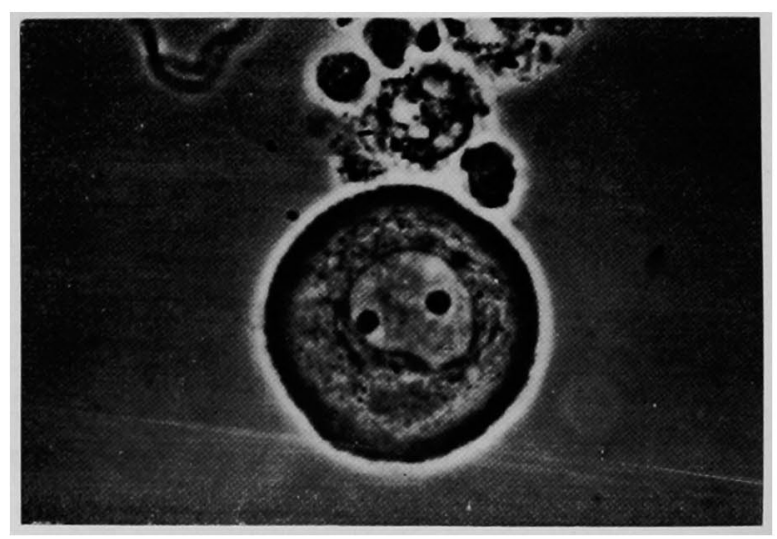

写真 9 体腔上皮腫細胞 (貼胞浮遊液培盖 P(UI-DLL) 